\title{
Collaborative Negotiated Feedback versus Teacher-written Feedback: Impact on Iranian Intermediate EFL Learners' Writing
}

\author{
Amir Marzban \\ English Language Department, Qaemshahr Branch, Islamic Azad University, Qaemshahr, Iran \\ Shahabeddin Mojtahedzadeh Sarjami (Corresponding Author) \\ English Language Department, Science and Research Branch, Islamic Azad University, Mazandaran, Iran
}

\begin{abstract}
Nowadays, having a good mastery in writing skills plays a pivotal role in achieving success. Hence, it seems that further improvement in teaching writing in general, and providing corrective feedback on students' errors in particular, might be necessary. There is no doubt that teacher written feedback plays an essential role in English writing classes. However, in spite of tremendous contribution of time and attempt from teachers and students, the feedback provision process is yet far away from ideal. Thus, a search for potential ways to improve the effectiveness of providing corrective feedback makes the motivation for this research study. The current study aimed at exploring the impact of Collaborative Negotiated Feedback on Iranian intermediate EFL learners' writing and compared it with Teacher-written feedback. The study involved two groups of Iranian Intermediate EFL learners (30 students in each), consisting male and female, aged from 19 to 25 , who were chosen through convenience sampling. In both groups, the same materials regarding different kinds of essay and paragraph organization were covered and implemented. While experimental group was provided with collaborative negotiated feedback, the control group was provided with the teacher's written feedback during the sessions. After Carrying out the treatment, the mean scores of the extracted data from pre-test/post-test of both groups were compared using independent sample t-test. The present researcher came to this conclusion that participants of the experimental group, who were exposed to collaborative negotiated feedback, outperformed the other group. The triangulation of three different sources; Pre/Post-test comparison, the questionnaire and interviews provide evidences in support of the efficacy of Collaborative Negotiated Feedback.
\end{abstract}

Index Terms — corrective feedback, written feedback, collaborative negotiated feedback

\section{INTRODUCTION}

Nowadays, having a great mastery of writing skill plays a crucial role in our lives. Writing is one of the bases that your occupation, your learning achievement, and your intellect will be judged upon. Writing is considered not only a tool to having success at school but to be successful in occupation in the future (Bradley-Johnson \& Lesiak, 1989). People knowledge can be revealed by the ways they write (Graham, 2005). As one technician suggests, writing in the mother tongue Language learning is bothersome for many students, but when it comes to writing in the second language the students' difficulty and ache are deteriorated (Gilmore, 2009). Hence, this skill of language should be seen as a crucial and vital component of Second and Foreign Language Learning.

Cooperative learning is one of techniques which can be employed in language pedagogy in general and teaching writing in particular. It seems that using collaborative activity in writing classes can be applicable in order to expand individuals' writing proficiency. Cooperative learning is one of the recent issues which has been supported by both researches and practical application. Cooperative learning helps students learn numerous things from their peers and also it motivates them to argue on a subject matter (Parker, 1985). As Bolling (1994) emphasized, cooperative learning has number of advantages such as increasing self-confidence, expanding communicative skills, reinforce critical thinking abilities, and take part in teaching-learning process actively.

Corrective feedback is one of the few areas in which, recently, become a subject of special interest among scholars and researchers. Teachers sometimes provide their students with feedbacks in the hope that they benefit from that but it may turn out to be more harmful than beneficial because it is not provided in a proper way. These kinds of feedbacks may result in many deleterious consequences such as lack of students' confidence or even frustration. So choosing a proper way of giving feedback to the learners in writing classes can be considered as one of the most significant issues in developing a writing course. The role of corrective feedback has been emphasized in most theories of second language learning and language pedagogy. In both behaviorist and cognitive theories of second language learning, corrective feedback is seen as a contributing factor to language learning (Ellis, 2009). In both structural and communicative approaches to language teaching, feedback is seen as a means of fostering learner motivation and 
ensuring linguistic accuracy (Ellis, 2009). While a significant number of studies have discussed the types and roles of feedback in this particular field, there are still debates about whether and how to provide second languagre students feedback on their written errors (Truscott, 1996, 1999, \& Ferris, 1999, 2002, 2004). Many researchers are currently examining the potentiality of interactional feedback which is obtained through negotiation in second language development (Pica, 1994; Long, 1996; Ferris, 1999, 2002, 2004; Truscott, 1996, 1999).

As a writing teacher, there has always been a question for the present researcher that how one can improve the efficiency of writing classes in general, and finds an applicable solution to providing effective feedback in particular. Hence, the main purpose of this study is to investigate the effectiveness of Collaborative Negotiated Feedback which is taken place in the class as the result of negotiation between teacher and students.

\section{REVIEW OF THE RELATED LITERATURE}

\section{A. Theoretical Background regarding Corrective Feedback}

In literature of foreign and second Language teaching corrective feedback is seen differently. As Ur (1996) summarized, feedback is given different role in different methods of Language teaching; In audio-lingual method, "negative assessment is to be avoided as far as possible since it functions as punishment and may inhibit or discourage learning"'. In humanistic methods, "assessment should be positive or non-judgmental"' in order to "promote a positive self-image of the learner as a person and language learner". But in skill theory, "the learner needs feedback on how well he or she is doing',

From the begining 1970's the field of second Language teaching has been predominated by communicative approach to language teaching. Communicative approaches aims at constructing an atmosphere that promote natural and lifelike acquisition, including incidental and implicit learning (Krashen \& Terrell, 1983; Long, 1985; Skehan, 1998). On the basis of the nativist ideology that first and second Language acquisition are follow from similar processes (e.g. Krashen \& Terrell, 1983), it is believed exposing to plenty comprehendible input is the necessary and sufficient condition for second Language acquisition. Hence, grammatical competence of second language was thought to be acquired automatically, without any need for corrective feedback (Krashen, 1981, 1982, 1985; Schwartz, 1993).

However, in the current views of Language teaching, acquisition of first and second languages are not considered the representatives of the same process, "the cognitive processes involved in L1 and L2 acquisition do not fully overlap" (Doughty, 2003). Consequently, in absolute absence of corrective feedback learners fail to achieve target-like accuracy and they may "proceduralize" some idiosyncrasies linguistic resolves for their communicative deficiencies, and as the result errors fossilization might be inevitable (Skehan \& Foster, 2001). Hence, in the modern view of Language teaching as Elis (2009) summarized, while corrective feedback has a place in accuracy work, it should be avoided in fluency work.

\section{B. A Review of Major Studies on Corrective Feedback}

There have always been some ambiguous and controversial issues centered around giving corrective feedback in process of Language teaching and learning. Ellis (2009) pointed out a number of controversies regarding to corrective feedback:

The controversy concerning CF centers on a number of issues: (1) whether CF contributes to L2 acquisition, (2) which errors to correct, (3) who should do the correcting (the teacher or the learner him/herself), (4) which type of CF is the most effective, and (5) what is the best timing for CF (immediate or delayed). These controversies will be discussed by drawing on both the pedagogic and SLA literature and by reference to both oral and written CF. (Ellis, 2009, p. 4)

\section{The Efficacy of Corrective Feedback}

One of the most critical questions which has existed regarding to feedback and teaching writing is that whether providing corrective feedback exerts an influential effect on writing improvement or not. In 1996, Truscott published an article under the title "The case against grammar correction in L2 writing classes" which caused a great argument about whether and how to provide corrective feedback on written grammatical errors which are made by second or foreign language learners (Truscott, 1996, 1999; Ferris, 1999, 2002, 2004). In 1996, Truscott came to the conclusion that correction of linguistic errors is not beneficial in teaching writing and be supposed to be excluded from teaching writings' programs. He supported his claim by two major reasons. Firstly, he indicated that correction of error as it is commonly exercised neglects the fact that second language learning is a slow and ongoing and process of acquiring the structures and forms. Secondly, he summarized a number of difficulties which exist in terms of practicality of providing corrective feedback in actuality of situation. Above and beyond that, he claimed that error correction can be operated as an obstacle in the way of productive aspects of the writing classes and waste a great deal of time and energy. Not surprisingly, ever since this claims have proposed, a great extent of controversial debates have arisen at articles and conferences (Ferris, 1999; Truscott, 1999).

A number of researches take position against Truscott, on the top of them Ferris (1999) claimed that Truscotts' conclusion was made overly strong and the evidences that he observed for making his conclusion was not sufficient at all. Ferris maintained that there were equally strong evidences for teachers to keep on providing corrective feedback. Even so, she did acknowledge that it is crucial to contemplate ways of improving issues emphasized by Truscott. Ur 
(1996) also comments about the importance of using feedback, "the learner needs feedback on how well he or she is doing" and "there is certainly a place for correction".

There are only a few researches which have directly attempted to investigate the effectiveness of giving corrective feedback on improvement of the accuracy on writing in second or foreign language learning and make a comparison between it and the groups of subjects who are not received feedback on their errors. A number of these researches (Kepner, 1991; Sheppard, 1992; Polio, Fleck, \& Leder, 1998) concluded that there is no meaningful difference in the accuracy of the students' writing, using corrective feedback. Even though, Fathman and Whalley (1990) initiated that the learners who received corrective feedback made fewer grammatical errors in comparison to those who were participated in purely meaning focused group. Hence, as Ferris (2002) and Truscott (1999) declare, further investigations are needed which observe the long-term impacts of such kinds of feedbacks and not simply compares the impacts of existence of them. Latterly, a number of recent studies (Sheen, 2007; Ellis, Sheen, Murakami, \& Takashima, 2008) have also produced evidences to show that written corrective feedback can be beneficial in language acquisition. Hence current researches have shifted from examining efficacy of corrective feedback to investigations of which types of them impacts better.

\section{Different Types of Corrective Feedback}

A number of investigations have also been investigating the efficiency of different kinds of corrective feedback on writing improvement. Some of them have distinguished between the dichotomy of direct (or explicit) and indirect (or implicit) corrective feedback (Robb, Ross, \& Shortreed, 1986; Ferris \& Hedgcock, 1998). Nassaji made distinction between two types of negotiated feedbacks in terms of explicitness:

"Interactional feedback can occur in different ways. In general, two broad categories of such feedback can be distinguished: reformulations and elicitations. Reformulations are those feedback strategies that rephrase a learner's erroneous production, providing the learner with the correct form. Elicitations, on the other hand, do not provide learners with the correct form. Instead, they push or prompt the learner directly or indirectly to self-correct."

(Nassaji \& Fotos, 2011, p.73)

The investigations on the effectiveness of the dichotomy of direct and indirect sorts of feedback provision have resulted to some kinds of findings in an interesting way. Although, the surveys which have been taken place, demonstrate the fact that teachers and learners have a tendency for explicit feedback (direct), rather than implicit feedback (indirect) (Komura, 1999; Ferris, Cheyney, Komura, Roberts, \& McKee, 2000; Rennie, 2000; Ferris \& Roberts, 2001), but a considerable number of studies manifest that indirect, implicit feedback result in higher level of linguistic accuracy over time (Lalande, 1982; Robb, Ross, \& Shortreed 1986; Frantzen, 1995; Lee, 1997; Ferris \& Helt, 2000).

Another issue concerning to the types of written corrective feedback is about combining different kinds of feedback strategies to increase its efficaciousness. A recent study on combination of different types of feedback on writing development suggests, " direct oral feedback in combination with direct written feedback had a greater effect than direct written feedback alone on improved accuracy over time''(Bitchener, Young, \& Cameron, 2005). Bitchener's (2008) investigation also led to positive evidences on the effect of written corrective feedback when it merges with oral metalinguistic explanation, but these investigations only represent findings in response to the upper intermediate second language learners.

Another dichotomy of feedback in respect to the types of written corrective feedback is the focused and unfocused types of correction. By unfocused approach to feedback provision, we mean having a variety of different categories and types of error correction to deal with, that "is likely to produce too much of a cognitive overload for learners" (Bitchener \& Knoch, 2008, p. 204). In order to deal with this criticism, some scolders tend to use focused feedback provision in which only few predetermined items will be rectified. These studies have resulted in positive findings when indicating particular categories of error (Doughty \& Varela, 1998). In recent times, Anderson (2010) looked into the serviceability of "tiered corrective feedback". He defined it as "the various stages of focused corrective feedback beginning with the concentration on one grammatical feature and proceeding upwards in increments of one" (p. 4). The findings of Anderson's study indicate that corrective feedback has influential impacts, when it targeted up to two categories of errors.

\section{Correction regarding Different Categories of Errors}

One of the fundamental questions in error correction is which categories of errors should be rectified and which of them should be tolerated. Corder (1967) suggests correcting 'errors' but not 'mistakes'. Errors occur because of a lack of knowledge but mistakes are simply performance errors. The distinction between 'local' and 'global' errors (Burt \& Kipersky, 1974) might be helpful:

Focus on 'global' rather than 'local errors'. Global errors are errors that affect overall sentence organization. Examples are wrong word order, missing or wrongly placed sentence connectors, and syntactic overgeneralizations. Local errors are errors that affect single elements in a sentence (for example, errors in morphology or grammatical functors).

(Burt \& Kipersky, 1974, p. 71) 
Ferris (2000) also suggests direct written corrective feedback at "treatable errors" might be more justifiable. He defines "treatable errors" as the errors that follow from a regular pattern or happened in "rule-governed way" (Ferris, Chaney, Komura, Roberts, \& McKee, 2000).

\section{Choice of Corrector: Teacher vs. peer}

With the gradual appearance of learner-centeredness concept in teaching methodologies, the implementation of peer feedback has got significantly more credibility in pedagogy. Nowadays, scholars frequently recommend giving students the opportunity to self-correct. Under condition that s/he is not able to self-correction, encourage other students to participate in process of correction (Hedge 2000). According to Rollinson (2005), using peer feedback is beneficial because:

1. Peer feedback is less threatening than teacher feedback. Because students are more comfortable with their classmates and therefore, getting corrected by own friends evokes less anxiety.

2. When correction comes from the teacher, it reinforces teacher's authority. In a traditional language class, the teacher is the authoritative figure and s/he is considered the sole source of knowledge. Students play the role of just a passive receiver of information. But through the practice of peer feedback, the classroom becomes less dominated by the teacher.

3. The involvement of peers in the correction process makes the classroom atmosphere more supportive and friendlier. (Rollinson, P., 2005, p. 25)

As the foregoing part have brought out, a brief literature regarding to the value and the kinds of corrective feedback on students' writing development have been reviewed, but it is equally clear that additional investigations center around corrective feedback might be helpful. As Hyland and Hyland (2006) commented "it is difficult to draw any clear conclusions and generalizations from the literature as a result of varied populations, treatments and research designs" (p. 84), the result of applying different kind of feedback in different context can differ to a great extent regarding to different nationality and different levels of proficiency. Hence, the following study is applied to examine the extent to which Collaborative Negotiated Feedback will help students to improve their writing skill.

\section{Statement of the Problem}

Different investigation have demonstrated the fact that the writing sections typically get fewer scores than reading, listening and speaking sections in different language exams. Students who have received several years of formal English instruction frequently face difficulties to produce the written form. The other phenomenon which is common among foreign language learners is rote learning. In this regard, the problem lies behind their passive participation; that is, they rely on teachers to a great extent and they are treated like empty vessels which need to be filled with facts and knowledge. This phenomenon leads the students to the regular spoon-feeding and strictness of the teaching processes which is known as teacher-centered classes. Thus, a need is felt for methods and strategies in which learners' participation and responsibility become more highlighted and these modifications can be done by providing different ways of corrective feedback on errors.

Undoubtedly, teacher written feedback on student's papers plays a significant role in English writing classes. Nevertheless, in spite of great deal of efforts from both students and teachers, the process teaching writing is still far away from ideal. Thus, a search for potential ways to improve the effectiveness of providing corrective feedback makes the motivation for this research study.

\section{Research Question}

In order to examine the effect of Collaborative Negotiated Feedback, the present study centered on the following question:

Is there any significant difference between Collaborative Negotiated Feedback and Teacher-Written Feedback in terms of their influence on the development of writing skill of Iranian intermediate EFL learners?

\section{E. Research Null Hypothesis}

Drawing on the research question presented above, the following null hypothesis is proposed in the present study:

There is no significant difference between Collaborative Negotiated Feedback and Teacher-Written feedback in terms of their influence on the development of writing skill of Iranian intermediate EFL learners.

\section{METHODOLOGY}

\section{A. Participants}

In order to carry out the present study and recruit research subjects, the researcher spread out advertisement in some educational places such as libraries, high-schools, universities and language institutes in Sari, to collect intermediate volunteers for participating in the current research. One hundred and eight EFL learners had volunteered to participate in this program. They were between the age range of 19-25 who were studying English in Sari, Mazandaran province as EFL learners. They were all native speakers of Persian including both males and females. The next step was choosing sixty homogenized participants for executing the study. The two homogenized groups of 30 learners were selected over administering Nelson proficiency test (Flowler \& Coe, 1976). In order to meet homogeneity criteria and choosing a 
sample with the more frequent variance, 60 volunteers who were at the range of one standard deviation above and one standard deviation below the mean were chosen. These 60 chosen participants were randomly assigned to 30 experimental and 30 control groups. The researcher has carried out this research at Hoonam Language Academy in Sari. Considering they are picked out from 108 available intermediate language learners, they should be considered as a Convenience sampling which may or may not be representative of the most characteristics of target population.

\section{B. Instruments}

In order to carry out the investigation three sets of tests were administered: The Nelson Quick Check A4 Test (1978) for the purpose of measuring the participants' level of proficiency and homogeneity. Pre-test and Post-test which are based on the IELTS Scoring Rubric (2012).

The Nelson Quick Check A4 Test consists of 25 multiple-choice items. The questions are separated and measure the examinees' general knowledge of grammar as well as vocabulary. The A pilot study was carried out with 30 intermediate learners for the sake of estimate the reliability of the Nelson Test through the application of Cronbach's alpha, one of the methods of estimating reliability and the reliability of the test is estimated at " 0.836 " is greater than "0.70", which indicates a high level of internal consistency for our scale in Nelson proficiency test.

Pre-test and Post-test which are based on the IELTS Scoring Rubric (2012) were administered to the participant of Experimental and Control groups. The IELTS Scoring Rubric (2012) was used as the criteria for rating of Post-test and Pre-test. This study takes advantage of Inter-Rater Reliability procedure in order to avoid subjectivity in scoring.

Along with the tests, the present researcher took advantage of using a teacher-made questionnaire to assess the attitudes and preferences of participants towards the newly implemented treatment on their writing tasks. The Content and Face validity of the questionnaire was confirmed by some ELT experts with PhD degrees in the field. The Construct validity of the questionnaire was measured by using Principal Component Analysis (PCA) technique. Its reliability was “.80” measured by "Cronbach's Alpha” measure of internal consistency.

\section{Procedures}

The investigation commenced on April 8, 2013 and came to an end on May 24, 2013. It consisted 12 sessions. In terms of materials selection, the book "Paragraph Development" was chosen as the main source for the application. Alongside the book, some supplementary materials regarding different types of essay writing were covered.

The lesson plan for both Control and Experimental groups was based on the following synopsis (Table 1):

TABLE 1:

OVERVIEW OF THE TEACHING PROCESS FOR EXPERIMENTAL GROUP

\begin{tabular}{|l|l|l|}
\hline Session Number & $\begin{array}{l}\text { First half of the class time } \\
\text { (Paragraph Development) }\end{array}$ & $\begin{array}{l}\text { Second half of the class time } \\
\text { (Essay Types) }\end{array}$ \\
\hline 1 & Chapter 1 & Review essay \\
\hline 2 & Chapter 2 & $\ldots \ldots \ldots \ldots \ldots$ \\
\hline 3 & Chapter $3 \& 4$ & Expository essay \\
\hline 4 & Chapter 5 & $\ldots \ldots \ldots \ldots \ldots$ \\
\hline 5 & Chapter 6 & Persuasive essay \\
\hline 6 & Chapter 7 & $\ldots \ldots \ldots \ldots \ldots$ \\
\hline 7 & Chapter 8 & Cause and Effect essay \\
\hline 8 & Review & Argumentative essay (part 1$)$ \\
\hline 9 & $\ldots \ldots \ldots \ldots$ & Argumentative essay (part 2$)$ \\
\hline 10 & $\ldots \ldots \ldots \ldots$ & Literary essay \\
\hline 11 & $\ldots \ldots \ldots \ldots$ & Informal essay \\
\hline 12 & $\ldots \ldots \ldots$. & Research essay \\
\hline
\end{tabular}

In the course of six weeks treatment, both groups attended to the class two sessions per week. In both groups the same materials regarding to writing structures, paragraph organization and types of essays were taught and implemented. As the homework, at the end of each session, a topic was chosen for writing assignment.

In terms of treatments, two different methods of error correction (corrective feedback) were applied. In the Experimental group, the half of the class time was devoted to teaching and the other half was devoted to Collaborative Negotiated Feedback. In Collaborative Negotiated Feedback procedure, the students were given a copy of other students writing assignment; that is, in each session, one of the students was assigned to provide other students with a copy of his or her writing assignment. In each session, heterogeneous groups of five members were formed. They were also given time to contemplate, collaboratively, the writing sample in terms of linguistic accuracy and organization through negotiation between members. Then, the writer of the text was assigned to read each paragraph. Subsequently, the writing was discussed sentence by sentence. The problematic areas could be pointed out either by teacher or students. Students were asked to participate in corrections of errors and express their own ideas about the way it can be rectified. The solution for the way the erroneous parts should be rectified was discussed by students and the teacher wrapped it up with the best available alternate. On the other hand, the Control group was provided with Teacher Written Feedback; that is, the assignment papers were gathered by teacher in order to be provided with feedbacks by the next session

In term of design of study, the present study followed pre-test/post-test design along with Control group. Due to the impact of having convenience sampling, the present study should be considered as a quasi-experimental research. This 
study took advantage of Gain Score design and Inter-rater Reliability procedure of scoring. It should be mentioned that the average amount of scores of Rater's 1 and Rater's 2 for each participant was considered as raw scores for all calculations in the study. While writing improvement was the dependent variable of the investigation, the independent variables were Collaborative Negotiated Feedback and Teacher-Written feedback.

TABLE 2:

SCHEMATIC REPRESENTATION OF DESIGN OF THE STUDY

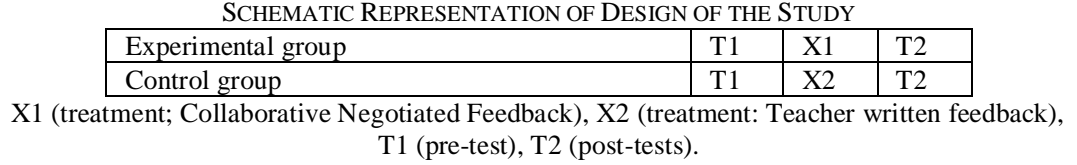

The triangulation of three different sources; Pre/Post-test comparison, the questionnaire and observations provided the present researcher with suitable pieces of evidence regarding the potentiality of administration collaborative negotiated feedback. In the current research, the following statistical analyses comprising descriptive statistics and inferential statistics were employed as follows. Sampling was conducted through the descriptive analysis (mean and standard deviation of the participants' scores) of Nelson Proficiency Test were estimated. "Cronbach's Alpha" measure of internal consistency was utilized in order to estimate the reliability of Nelson Proficiency Test. Since two different raters scored the Pre-test and Post-test, the correlation was used as the index of Inter-Rater reliability. Hence, "Pearson product-moment correlation coefficient" and its non-parametric equivalent "Spearman's correlation" were utilized for examining the reliability of Pre-test and Post-test. Inter-Rater reliability of Pre-test of writing for Experimental group was " $r_{s}=0.94$ ", post-test of writing for Experimental group " $r_{s}=0.95$ ", pre-test of writing for Control group " $r_{s}=0.93$ ", and post-test of writing for Control group " $r_{s}=0.97$ ". "Levene's test" was employed for reassuring the homogeneity of Control and experimental groups At Pre-test. "Kolmogorov-Smirnov" test of normality was used for checking the normality of all sets of scores. In order to compute the amount of Gain scores for each group, every participant's Posttest score was subtracted from his/her Pre-test score. Considering each test in this study has scored by two separate raters, an average amount of the two scores for each student is regarded as the raw score for each of them. With this procedure, two sets of gain scores, one for Experimental group and the other for Control group were obtained. In order to compare the means between the Gain scores of Control and Experimental groups, "Independent Sample T-Test" was applied to see whether the difference between groups means is statistically influential or not. The construct validity of the questionnaire was measured by using Principal Component Analysis (PCA) technique. Its reliability was measured by "Cronbach's Alpha" measure of internal consistency. It should be mentioned that in doing all these statistical processes "SPSS software (version 17)" was employed.

\section{RESULTS AND DisCUSSIONS}

As pointed out above, the present study aimed at investigating the effectiveness of Collaborative Negotiated Feedback which is carried out in the class as the result of negotiation between teacher and students on development of the writing performance of Iranian intermediate EFL learners, as well as, to compare it with Teacher-Written feedback which is the current norm of the most writing classes. The null hypothesis was that there is no significant difference between Collaborative Negotiated Feedback and Teacher-Written Feedback in terms of their influence on the development of writing skill of Iranian intermediate EFL learners. The t-test result for the hypothesis comes in the following table.

TABLE 3:

INDEPENDENT SAMPLES TEST FOR COMPARING THE MEANS OF CG AND EG

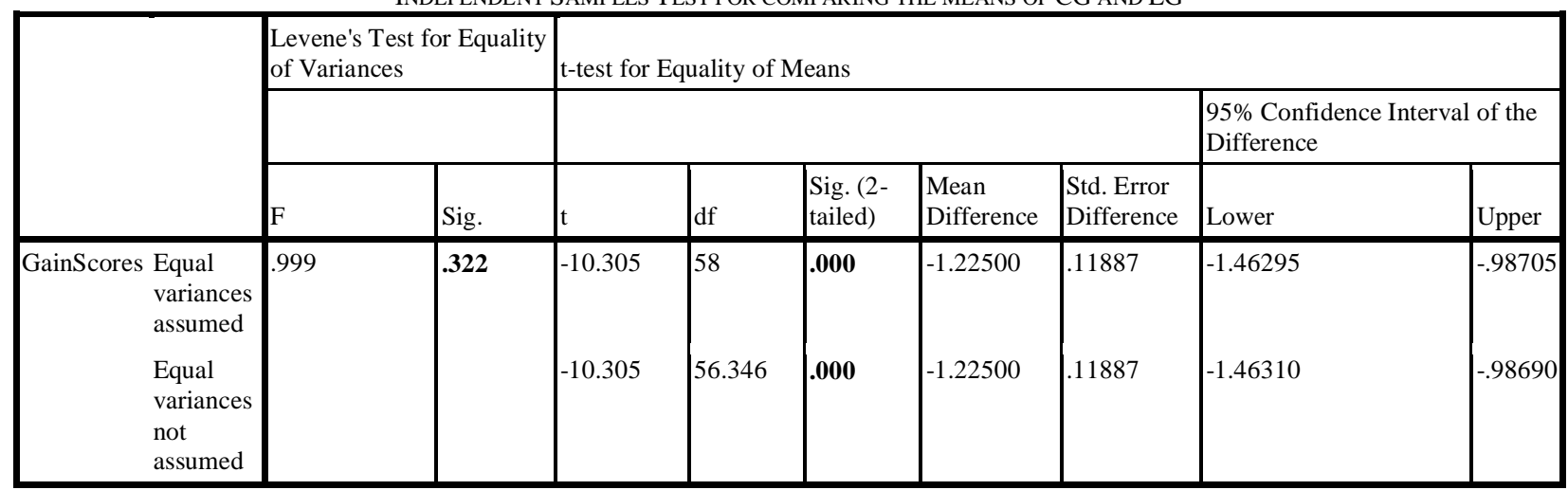

As "Table 3" demonstrates, in the Levene's Test for equality of variances (first row in the Table), the observed significance is ".32" > ".05", so we can safely assume the equal variances exist. As the value being observed in the "Sig. (2-tailed)" row is ".00" and less than ".05" so, the observed $\mathrm{P}$ is less than the cutoff point $(\mathrm{P}=.05)$ and the null 
hypothesis is strongly rejected and confirm a meaningful difference. The difference between the means of gain scores between Control and Experimental groups is represented in following Bar graph:

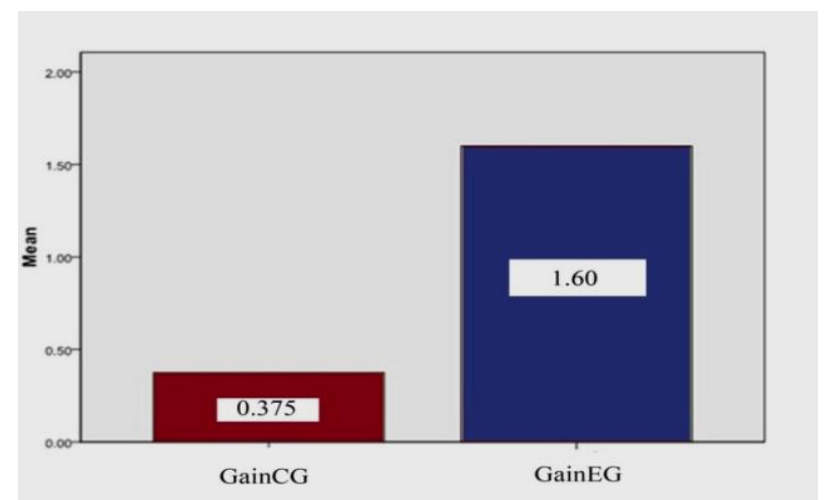

Figure 1: means difference of gain scores between control and experimental groups

It can be deduced that the participants of the Control group, comparatively, achieved the lower gain scores than the participants of the Experimental group at the end of the program and it demonstrate the efficacy of Collaborative Negotiated Feedback.

Beside, the present researcher by running a Paired Samples T-test between the scores of Pre-test and Post-test for the Control group tried to examine the potentiality of teacher-written feedback itself. The corresponding t-test results can provide further insights.

TABLE 4:

PAIRED SAMPLES STATISTICS FOR CONTROL GROUP

\begin{tabular}{|ll|l|l|l|l|}
\hline & & Mean & $\mathrm{N}$ & Std. Deviation & Std. Error Mean \\
\hline Pair 1 & PreCG & 4.6083 & 30 & .69071 & .12611 \\
& PostCG & 4.9833 & 30 & .98027 & .17897 \\
\hline
\end{tabular}

TABLE 5:

PAIRED SAMPLES TEST FOR CONTROL GROUP

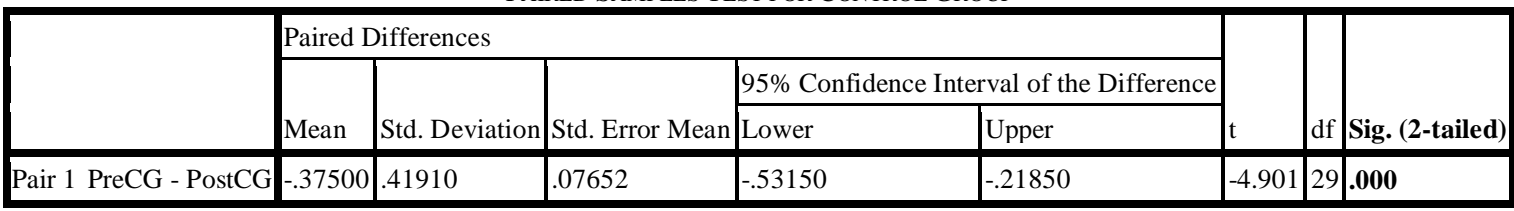

As it is reported in "Table 5", the "Sig. (2-tailed)" is ".00" and less than "0.05" so, the observed P is less than the cutoff point $(\mathrm{P}=.05)$. On the other hand, by looking to "Table 4" we can see that the mean of Post-test is greater than Pre-test and it confirms the fact that the Teacher-Written feedback could still be contemplated as an influential method of feedback provision, when other creative methods are not feasible.

The Descriptive Statistics of the teacher made questionnaire is presented in "Table 6" as follow:

TABLE 6:

DESCRIPTIVE STATISTICS TEACHER MADE QUESTIONNAIRE

\begin{tabular}{|l|l|r|r|r|r|}
\hline & $\mathrm{N}$ & Minimum & Maximum & Mean & Std. Deviation \\
\hline Q1 & 30 & 3 & 5 & 3.90 & .803 \\
Q2 & 30 & 3 & 5 & 4.40 & .621 \\
Q3 & 30 & 2 & 5 & 3.73 & .785 \\
Q4 & 30 & 3 & 5 & 3.93 & .691 \\
Q5 & 30 & 3 & 5 & 3.77 & .774 \\
Valid N (listwise) & 30 & & & & \\
\hline
\end{tabular}

The descriptive statistics in "Table 6" indicates that the mean scores of all participants on the items of the scale was greater than '2.86' which was set the cutoff point (because the mean score of population was '2.86'). The high mean scores on these items verifies that the participants have a positive attitude towards learning writing by receiving collaborative negotiated feedback.

One of the pivotal reasons, in which, Collaborative Negotiated Feedback outperforms Teacher-Written Feedback was the existence of interaction element. Considering the benefits which scholars have taken in to account for having interaction in the classroom (Pica, 1994; Long, 1996; Truscott, 1996, 1999; Ferris, 1999, 2002, 2004), it seems that the 
combination of interaction and feedback provision in the way that correction of errors have taken place through negotiation plays the key role in the achieving success. Secondly, when a written feedback is given to students, there is no guarantee that what the teacher writes on the paper is understood the same way by the learner. This problem had been solved by Collaborative Negotiated Feedback as far as the corrections have been done at the presence of students and all the ambiguities have been solved through questioning and answering. The next point is that other students were able to benefit from the correction of an error performed by their peers. Another element was having active participation in the class which is promoted through the practice of Collaborative Negotiated Feedback.

This study has supported the benefit which some scholars have considered for having interaction in the classroom (Pica, 1994; Long, 1996; Truscott, 1996, 1999; Ferris, 1999, 2002, 2004). Also, it has supported Hedge (2000) preference for self-correction and Rollinson (2005) orientation for using peer's feedback instead of teacher's feedback. The findings have also supported Burt \& Kipersky's (1974) recommendation, in which, focus on 'global' rather than 'local errors' is beneficial in error correction process. This study has provided pieces of evidence in support of Bitchener \& Knoch (2008), Doughty \& Varela (1998), and Anderson (2010)'s investigations, in which, providing focused feedback on only few predetermined items would be more advantageous as opposed with unfocused types of correction.

\section{CONCLUSIONS AND IMPLICATIONS}

In this study the present researcher intensely observed that using Collaborative Negotiated Feedback enhanced process of teaching writing more than one way. Students' autonomy, alacrity, active participation, and better performance are all observed through the practice of this method of feedback provision. The triangulation of three different sources; Pre/Post-test comparison, the questionnaire and observations provide evidences in support of the efficacy of Collaborative Negotiated Feedback. Hence, it is safe to conclude that there is a significant difference between Collaborative Negotiated Feedback and Teacher-Written Feedback in terms of their influence on the development of writing skill of Iranian intermediate EFL learners. The Collaborative Negotiated Feedback outperforms the Teacher-Written Feedback more than one way. It is also confirmed that the Teacher-Written Feedback could still be contemplated as an influential method of feedback provision, when other creative methods are not feasible.

In this study the following pedagogical implications for textbook developers, foreign language teachers, and learners can be taken into consideration:

1. Instructors and program developers should be aware of potentiality of interaction and collaborative learning. In doing so, they will be able to help their students to improve their writing proficiency. Teachers can put emphasis on interaction which can bring about many positive outcomes. This study is significant to understanding better how we can encourage fun cooperative learning atmospheres that permit students to act together and develop both socially and intellectually. The Collaborative Negotiated Feedback is one of the strategies which are fully capable of doing so.

2. Collaborative Negotiated Feedback can help materials developers and Syllabus designers incorporate more motivating and challenging exercises, activities, tasks, and materials which can encourage students to participate more effectively and eagerly in English classes.

3. The results of this study are beneficial for language testing. Instead of the threatening and unpleasant testing, teachers can evaluate students constantly in a fun cooperative-competitive class during the term.

4. Collaborative Negotiated Feedback can save the teachers' time and energy. The teachers don't need to carry a number of papers home to provide feedback on them.

5. Teachers are expected to gradually release responsibility to the students, allowing them to do what they can on their own. Teachers are allowed to intervene only when support is needed. Teachers also can encourage language learners to seek out appropriate strategies and use them independently to correct themselves. The Collaborative Negotiated Feedback is one of the strategies which fully capable of doing so.

\section{REFERENCES}

[1] Anderson, T. (2010). The effects of tiered corrective feedback on second language academic writing. An unpublished thesis from the University of British Columbia, Vancouver, Canada.

[2] Bitchener, J. (2008). Evidence in support of written corrective feedback. Journal of Second Language Writing, 17(2), 102-118.

[3] Bitchener, J., \& Knoch, U. (2008). The value of a focused approach to written corrective feedback. ELT Journal, 63(3), 204211.

[4] Bitchener, J., Youmg, S., \& Cameron, D. (2005). The effect of different types of corrective feedback on ESL student writing. Journal of Second Language Writing, 14(3), 191-205. Retrieved November 17, 2012 from http://www.sciencedirect.com/science/article/pii/S 1060374305000366.

[5] Bolling, A. L. (1994). Using group journals to improve writing and comprehension. Journal on Excellence in College Teaching, 5(1), 47-55.

[6] Bradly-Johnson, S., Lesiak JK (1989). Problem in written expression: Assessment and remediation. New York: Guilford.

[7] Burt, M. K., \& Kiparsky, C. (1974). Global and local mistakes. In J. Schumann, \& N. Stenson (Eds.), New frontiers in second language learning (pp. 71-80). Rowley, MA: Newbury House.

[8] Corder, S. P. (1967). The significance of learners' errors. International Review of Applied Linguistics, 5(1), 161-170. 
[9] Doughty, C. J. (2003). Instructed SLA: Constraints, compensation, and enhancement. In C. J. Doughty \& M. H. Long (Eds.), Handbook of second language acquisition (pp. 256-310). Oxford: Blackwell.

[10] Doughty, C., \& Varela, E. (1998). Communicative focus on form. In C. Doughty \& J. Williams (Eds.), Focus on form in classroom second language acquisition (pp.114-138). Cambridge: Cambridge University Press.

[11] Ellis, R. (2009). Corrective feedback and teacher development. L2 Journal, 1(1). Retrieved November 17, 2012 from http://escholarship.org/uc/item/2504d6w3.

[12] Ellis, R., Sheen, Y., Murakami, M., \& Takashima, H. (2008).The effects of focused and unfocused written corrective feedback in an English as a foreign language context. System, 36, 353-371.

[13] Fathman, A., \& Whalley, E. (1990). Teacher response to student writing: Focus on form versus content. In B. Kroll (Ed.), Second language writing: Research insights for the classroom (pp. 178-190). Cambridge: Cambridge University Press.

[14] Ferris, D. R., \& Hedgcock, J. S. (1998). Teaching ESL composition: Purpose, process, and practice. Mahwah, NJ: Lawrence Erlbaum Associates.

[15] Ferris, D. R. (1999). The case for grammar correction in L2 writing classes. A response to Truscott (1996). Journal of Second Language Writing, 8, 1-10.

[16] Ferris, D.R., \& Helt, M. (2000). Was Truscott right? New evidence on the effects of error correction in L2 writing classes. Paper presented at Proceedings of the American Association of Applied Linguistics Conference, (pp.11-14), Vancouver, B.C.

[17] Ferris, D. R., \& Roberts, B. (2001). Error feedback in L2 writing classes: How explicit does it need to be? Journal of Second Language Writing, 10, 161-184.

[18] Ferris, D. R. (2002). Treatment of error in second language student writing. Ann Arbor: University of Michigan Press.

[19] Ferris, D. R. (2004). The "Grammar Correction" debate in L2 writing: Where are we, and where do we go from here? (and what do we do in the meantime. . .?). Journal of Second Language Writing, 13, 49-62.

[20] Ferris, D. R., Chaney, S. J., Komura, K., Roberts, B. J., \& McKee, S. (2000). Perspectives, problems, and practices in treating written error. In Colloquium presented at International TESOL Convention, (pp. 14-18), Vancouver, B.C.

[21] Flowler, W. S., \& Coe, N. (1976). Nelson English language test. London: Bulter and Tannerltad.

[22] Frantzen, D. (1995). The effects of grammar supplementation on written accuracy in an intermediate Spanish content course. Modern Language Journal, 79, 329-344.

[23] Gilmore, A. (2009). Using online corpora to develop students' writing skills. ELT Journal, 63(4), 363-372.

[24] Graham DC. (2005). Cooperative learning methods and middle school student. Ph. D.Thesis, Capella University, Minneapolis, USA.

[25] Hedge, T. (2000). Teaching and learning in the language classroom. Oxford: Oxford University Press.

[26] Hyland, K., \& Hyland, F. (2006). Feedback in second language writing: Contexts and issues. Cambridge: Cambridge University Press.

[27] Kepner, C. G. (1991). An experiment in the relationship of types of written feedback to the development of secondlanguage writing skills. Modern Language Journal, 75, 305- 313.

[28] Komura, K. (1999). Student response to error correction in ESL classrooms. Master's thesis, California State University, Sacramento.

[29] Krashen, S. (1981). Second language acquisition and second language learning. Oxford: Pergamon Press.

[30] Krashen, S. (1982). Principles and practice in second language acquisition. Oxford: Pergamon Press.

[31] Krashen, S. (1985). The input hypothesis: Issues and implications. London: Longman.

[32] Krashen, S., \& Terrell, T. (1983). The natural approach: Language acquisition in the classroom. Oxford: Pergamon Press.

[33] Lalande, J. F. (1982). Reducing composition errors: An experiment. Modern Language Journal, 66, 140-149.

[34] Lee, I. (1997). ESL learners' performance in error correction in writing: Some implications for college-level teaching. System, $25,465-477$.

[35] Long, M. H. (1985). Input and second language acquisition theory. In S. M. Gass, \& C. G. Madden (Eds.), Input in second language acquisition (pp. 377-393). Rowley, MA: Newbury House.

[36] Long, M. (1996). The role of the linguistic environment in second language acquisition. In W. Ritchie, \& T. Bhatia (Eds.), Handbook of second language acquisition (pp. 413-468). San Diego: Academic Press.

[37] Nassaji, h., \& Fotos, S. (2011). Teaching grammar in second language classrooms. New York: Taylor \& Francis group.

[38] Parker, R. (1985). Small-group cooperative learning. The Education Digest, 51, 44-46.

[39] Pica, T. (1994). Research on negotiation: What does it reveal about second language learning conditions, processes, and outcomes? Language Learning, 44, 493-527.

[40] Polio, C., Fleck, N., \& Leder, N. (1998). "If only I had more time": ESL learners' changes in 7, linguistic accuracy on essay revisions. Journal of Second Language Writing, 7, 43- 68

[41] Rennie, C. (2000). Error feedback in ESL writing classes: What do students really want? Master's Thesis. California State. University, Sacramento.

[42] Robb, T., Ross, S., \& Shortreed, I. (1986). Salience of feedback on error and its effect on EFL writing quality. TESOL Quarterly, 20, 83-93.

[43] Rollinson, P. (2005). Using peer feedback in the ESL writing class" ELT Journal, 59(1), 23- 30

[44] Schwartz, B. D. (1993). On explicit and negative data effecting and affecting competence and linguistic behavior. Studies in Second Language Acquisition 15(2), 147-163.

[45] Sheen, Y. (2007). The effect of focused written corrective feedback and language aptitude on ESL learners' acquisition of articles. TESOL Quarterly, 41, 255-283.

[46] Sheppard, K. (1992). Two feedback types: Do they make a difference? RELC Journal, 23, 103-110.

[47] Skehan, P. (1998). A cognitive approach to language learning. Oxford: Oxford University Press.

[48] Skehan, P., \& Foster, P. (2001). Cognition and tasks. In P. Robinson (Ed.), Cognition and second language instruction (pp. 183-205). Cambridge: Cambridge University Press.

[49] Truscott, J. (1996). The case against grammar correction in L2 writing classes. Language Learning, 46, 327-369. 
[50] Truscott, J. (1999). The case for "the case for grammar correction in L2 writing classes": A response to Ferris. Journal of Second Language Writing, 8, 111-122.

[51] Ur, P. (1996). A course in language teaching. Cambridge: Cambridge University Press.

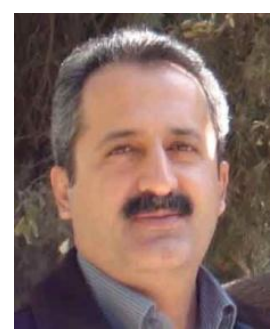

Amir Marzban is an assistant professor of TESOL at Islamic Azad University, Qaemshahr branch. His research interests include conversation analysis, L2 reading \& writing, CALL, and teacher education. He has published in both Iranian and International journals and also has presented in many international conferences.

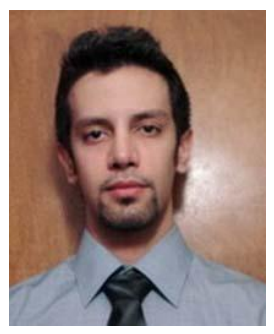

Shahabeddin Mojtahedzadeh Sarjami is an English teacher with M.A degree in TEFL. He received his Associated degree in English Language Teaching from Islamic Azad University, Zanjan branch. He received his B.A in English Translation from Parsa University, Babolsar. He received his M.A from Islamic Azad University, Mazandaran Science and Resaerch Branch. His main research interests are English language teaching with the focus on literacy skills, corrective feedback, team work, and automaticity. 